\title{
Tax Planning Strategy of Service Industry in Jilin Province
}

\author{
Yuhong Wang \\ Changchun University of Finance and Economics \\ Changchun, China
}

\begin{abstract}
Service industry is an important indicator to measure the comprehensive competitive strength of a region. However, the development level of service industry in Jilin Province has a large gap compared with that of other provinces. This paper carries out elaboration and case analysis of the tax planning strategy of the service industry from aspects such as tax preferential policies, value-added tax, income tax, and real estate tax in the province, which will be beneficial to the service industry in Jilin Province to save tax costs, increase cash flow, and has great significance of the development of modern service industry in Jilin Province.
\end{abstract}

Keywords—service industry in Jilin Province; tax planning; preferential tax policies; replacement of business tax with VAT

\section{INTRODUCTION}

The development level of the service industry directly affects the modernization level and competitiveness of a region. However, compared with that in other provinces, the development level of the service industry in Jilin Province is relatively backward, and the overall development level is not high. Doing tax planning well for the service industry will help prevent tax risks, save tax costs, and increase cash flow, which is of great significance to the development of modern service industry in Jilin Province.

\section{RELEVANT PREFERENTIAL TAX POLICIES FOR SERVICE INDUSTRY IN JILIN PROVINCE}

In order to thoroughly implement the "Three Fives" strategy, accelerate the optimization and upgrading of the industrial structure, and promote the comprehensive revitalization of the old industrial bases in Jilin Province, the province has implemented the problem solving work of the service industry, and formulated a series of preferential policies on taxes and fees, for example: among the 32 policies in the Notice of the People's Government of Jilin Province on Printing and Distributing Certain Policies for Accelerating the Leap-forward Development of the Service Industry (JZF [2012] No. 33), there are 8 are preferential policies on taxes and fees; the preferential policies on property tax and land use tax in
Article 9 in Several Implementation Opinions of the Jilin Provincial Party Committee and the People's Government of Jilin Province on Accelerating the Development of the Service Industry (JF [2016] No. 6); and relevant tax incentives for animation companies stipulated in the Notice on the VAT and Business Tax Policies of the Animation Industry (CS [2013] No. 98), and so on.

\section{TAX PLANNING STRATEGY OF SERVICE INDUSTRY IN JILIN PROVINCE}

\section{A. VAT}

\section{1) Taxpayer identity planning}

After the "replacement of business tax with VAT", the tax rate of general taxpayers of the service industry in Jilin Province increased from $3 \%$ to $10 \%$. Since less input tax invoices can be obtained in the initial cost and expense items, the tax burden is generally serious. However, if the status is small-scale taxpayers, the applicable tax rate is 3\%. Although the input cannot be deducted, there is still a large reduction in tax burden. Therefore, it can be considered to split the company into several subsidiaries with sales of less than 5 million yuan, and register them as small-scale taxpayers that can enjoy preferential policies of small-scale taxpayers. However, in the actual work, a variety of factors have to be considered and decisions shall be made after a comprehensive measurement without losing customers.

\section{2) Tax shifting planning}

Tax shifting refers to the tax planning method that shifts the tax burden that should be afforded to buyers or suppliers by using the market pricing autonomy. In the business process of service industry companies, the following shifting ways can be used to reduce the company tax burden:

\section{a) Forward shifting}

Companies raise the selling price to shift the VAT payable to buyers, thereby achieving the purpose of reducing the tax burden as a whole.

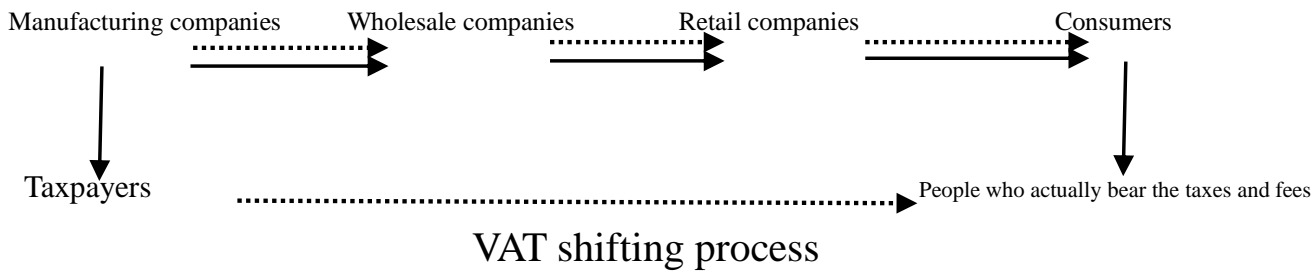

Fig. 1 Forward shifting process diagram 
For example: in order to shift the VAT tax burden, a leasing company raises the unit price of its leasing from 100 yuan to 150 yuan, and its tax planning process is as follows: the VAT output tax payable before the rise in price $=100 /(1$ $+16 \%) \times 16 \%=13.79$ (yuan); the VAT output tax payable after the rise in price $=150 /(1+16 \%) \times 16 \%=20.69$ (yuan). From the perspective of the amount of VAT tax payable, the tax payable after the rise in price is higher. However, considering the increase in income brought by the

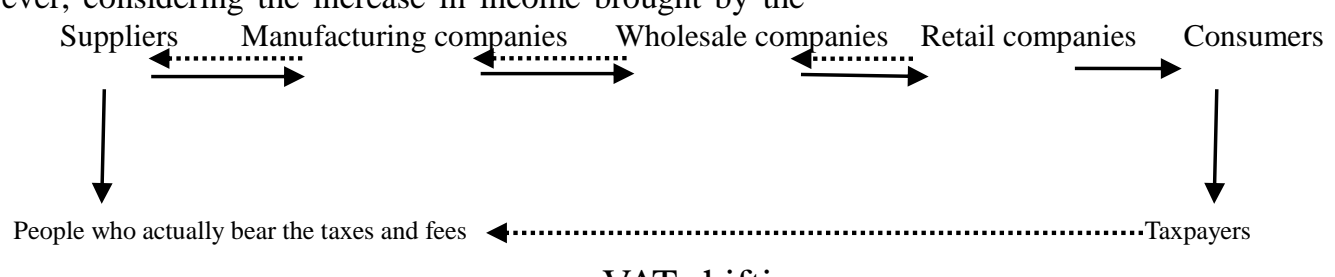

VAT shifting process

Fig. 2 Backward shifting process diagram

For example: the price of a leasing company's purchase of leased equipment is 160,000 yuan. After negotiating with the supplier, the purchase price is lowered to 140,000 yuan. Then: the input tax after the price reduction $=14 /(1+16 \%) \times 16 \%$ $=1.93$ (ten thousand yuan); the input tax before the price reduction $=16 /(1+16 \%) \times 16 \%=2.21$ (ten thousand yuan); Although the input tax deductible after the price reduction is 2,800 yuan less, the price has been reduced by 20,000 yuan, with 17,200 yuan saved after comprehensive consideration.

\section{c) Mixed shifting}

It refers to the tax shifting method with the combination of forward shifting and backward shifting, which shifts the VAT to multiple parties of suppliers and customers. For example, the aforementioned leasing company shifts a part of the VAT to the supplier, while shifting part of the VAT to the lessee by means of raising the rental price.

\section{d) Diffused shifting}

It refers to companies' offset of the VAT generated in the current period by reducing the cost. Taking the aforementioned leasing company as an example, in the case that the purchase price is not lowered nor the leasing service price is increased, it uses the ways such as the improvement of work efficiency, the reduction of energy consumption, and cost saving to offset the VAT payable.

\section{3) Tax preferential policy planning}

In order to promote the development of the service industry, Jilin Province has formulated a series of tax preferential policies. Companies should be proficient in these policies and make full use of preferential policies to reduce the company tax burdens.

For example: Notice on Certain Policies for Accelerating the Leap-forward Development of the Service Industry of Jilin Province stipulates: The animation products developed and produced by animation companies in our province can enjoy the preferential tax policies of the current software industry in the country. After the VAT is levied at the rate of $16 \%$, the immediate levy and refund preferential policy will be carried out to the part of the actual tax exceeding 3\%. It should be noted that: the "part of the actual tax exceeding 3\%" here refers to the part of the actual VAT paid by companies that exceeds $3 \%$ of their income in the same year. rise in price, there is an income increase of 43.1 yuan as a whole compared with that before the rise in price.

\section{b) Backward shifting}

Companies lower the purchase price and shift the taxable amount to suppliers. For example, in the previous example, the leasing company transfers the VAT to the supplier by reducing the purchase price of the vehicle, maintenance and repair costs, and fuel price, etc.
Assume that the input tax deductible of an animation company is 350,000 yuan in the same year, and the income of the self-developed and produced animation products is $10,000,000$ yuan excluding tax, then:

The VAT output tax payable $=1000 \times 16 \%=1.6$ million yuan

The actual VAT paid in this year $=160-35=1.25$ million yuan.

And the actual tax ratio of the animation company $=136 /$ $1000=13.6 \%$

According to the preferential tax policies of Jilin Province, tax refund will be given to the actual tax that exceeds $3 \%$, then:

Company tax refund rate $=13.6 \%-3 \%=10.6 \%$

The actual tax refund amount $=1000 * 10.6 \%=1.06$ million yuan

It can be seen that if certain tax preferential policies for the service industry in our province are well mastered, it can also bring good tax-saving effects to companies.

\section{B. Income tax}

\section{1) Advertising and business publicity costs planning}

When service industry companies conduct income tax planning, if they can make good use of advertising business publicity costs, the taxes and fees may be reduced to a larger extent. However, it should be noted that: China's taxation laws have strict provisions on the deduction of advertising costs, which must meet three conditions at the same time: disseminated through compliant media; produced by specialized agencies approved by the industry and commerce department, costs have been paid and invoice has been received; According to the provisions of China's taxation laws, when deducting advertising business publicity costs, it should be deducted according to the $15 \%$ of income; the excess portion can be deducted in subsequent years, which provides planning space for companies to pay income tax.

For example: the majority income of a film and television company comes from advertising income and movie projection income, then the company's business publicity costs and advertising costs are relatively high, and the advertising publicity costs in the sales expenses of the film company 
accounts for $80.87 \%$. When the film and television company sells products and provides movie projection services, sometimes, in order to attract customers to increase its income, it will give customers some gifts and derivative products related to the film. Then, these costs can be included in advertising and business publicity costs, including the parts that cannot be deducted before the tax payment into the business publicity costs, thus carrying out the pre-tax deduction. If the gift is entrusted to be processed or produced by the company itself, and the company's image or product mark is printed on the gift, which can directly play a certain publicity role, this part of costs can be deducted before tax as the advertising and business publicity costs, thus reducing the taxable income of the company, and playing the role of saving taxes. Secondly, if the film and television company mainly relies on the income from the movie projection service as the main income, then, when it holds film exchange meetings, exhibitions and the premieres, the expenses incurred can all be deducted through including them into business publicity costs for pre-tax deduction. It can be seen from the above cases that as long as the service industry companies can reasonably use the advertising and publicity costs, reduce the taxable income and increase the pre-tax deduction, they can reduce the income tax and increase the after-tax profit.

\section{2) Public welfare donation tax planning}

Law on Corporate Income Tax stipulates that for the expenditures for public welfare donations incurred by a company, the portion within $12 \%$ of the total annual profits is permitted to be deducted when calculating the taxable income; the portion that exceeds the $12 \%$ of the total annual profits will be deducted when calculating the taxable income within three years after the shifting is permitted.

If the total profit of a service industry company in 2018 is 207.064 million yuan, then the maximum deduction amount of corporate public welfare donation is 24.8477 million yuan. However, the actual public welfare donation is 342,300 yuan, which is only $0.16 \%$ of the total profit of the same year. Therefore, in combination with the actual situation and strategic objectives of the company, we can consider raising the public welfare donation to $0.2 \%$ of the total profit, that is, to increase 71,800 yuan, then, the tax of 18,000 yuan can be offset for the company, which can enhance the corporate market image and increase the market share. In addition, the company has another donation plan of 50,000 yuan, which can be donated to social welfare organizations or non-profit organizations, and obtain legal certificates at the same time, then, the50,000 yuan which cannot be deducted before tax can be included into the public welfare donations and be fully deducted before tax, which will save the corporate income tax of 12,500 yuan.

\section{3) Tax preferential policy tax planning}

The income tax preferential policies for service industry companies are inseparable from the industry's own industry value and the main advantages of its own business development investment. Firstly, from the perspective of business type, for example: the high-tech enterprise income tax rate is $15 \%$. For those companies whose R\&D investment meets the high-tech enterprise standards, they can apply to the Science and Technology Bureau for high-tech enterprises. After the application is approved, they can enjoy the preferential tax of $15 \%$ of the income tax rate. The R\&D costs of high-tech enterprises can enjoy the preferential policies of pre-tax deduction of income tax, which is beneficial to further increase the pre-tax deduction of corporate income tax, and can fundamentally reduce corporate income tax. For example, if a company is engaged in the software service industry with a dozen of projects that have been independently developed and formed patents, and eight projects under research, and belongs to the high-tech enterprise, the income tax rate is directly reduced by $10 \%$ in 2018 , and the taxable income is 10 million yuan, then the company can enjoy the preferential income of 1 million yuan while calculating the income tax payable according to the income tax rate of $15 \%$. Besides, in the aspect of the R\&D expenses for high-tech enterprises, it can also enjoy the income tax reduction and exemption of 600,000 yuan, which can be seen that the tax preferential policies have brought the unprecedented development opportunities for the fast-growing service industry enterprises.

\section{Property tax and land use tax}

According to the preferential policies of Jilin Province, the newly-established service industry enterprise, for example, the address is in the provincial modern service industry gathering area, is exempted from urban land use tax and property tax for self-use real estate land for 3 years; if it is not in the gathering area, the land use tax and property tax of the land for self-use will be exempted within 2 years; If it is newly operated by its own house and the original registered usage of house is unchanged, the property tax will be exempted for 2 years; The current administrative and institutional fees are charged at the lower limit for service industry companies. Newly-established service industry companies can choose to start in the gathering area of service industry or use their own houses, which will save a lot of property tax and land use tax for them.

\section{CONCLUSION}

The service industry in Jilin Province still has a long way to go in the future. However, due to this, it has even more potential. Our province is striving to build a modern industrial development system that takes serving economy as its main part, and the service industry is an extremely important part in this system. Companies should fully grasp the tax policies of Jilin Province and the state, and do a good job in tax planning in line with national policies, which not only can reduce the tax burden for the company, but also can promote the comprehensive development of the service industry in Jilin Province, thus making the service industry in our province achieve the change like the nirvana of phoenix.

\section{ACKNOWLEDGMENT}

This paper is the research result of the Tax planning strategy and feasibility research of the service industry in Jilin Province (No. 15270669981467) of the "13th Five-Year" Social Science Project of the Education Department of Jilin Province.

The periodic achievement of Education Department of Jilin Province "13th Five Year Plan" Social Science Project "Small Enterprise Accounting Criterion Operation Countermeasures Research_-Taking the Small Enterprises of Jilin Province as an Example" (Contract No.: JJKH20181356SK)

The periodic achievement of Philosophy and Social Science Planning Project of Jilin Province "Study on Execution Effectiveness of Internal Control and Improvement Strategy of SME of Jilin Provinve" (Contract No.: 2019B54) 


\section{REFERENCE}

[1] The People's Government of Jilin Province. Several Implementation Opinions on Accelerating the Development of the Service Industry. No.6 in 2016

[2] Huijie WANG. Research on the VAT tax planning of SZ car rental company under the background of "camp changed to increase" [D]. Tianjin University of Commerce, 2017.

[3] Perry A. Trunick. The Many Faces of Logistics in China [J]. Logistics Today, 2012 (1): 48-53.

[4] The Chinese Institute of Certified Public Accountants Taxation Laws [M]. Economic Science Press, 2019.

[5] An CHEN. Research on corporate tax planning under the new stage of the replacement of business tax with VAT [J]. Commercial Accounting, 2013 (17).

[6] Peng TANG, Shuang MU. The impact of the "replacement of business tax with VAT" on logistics enterprises [J]. Zongheng Jingwei, 2015 (3). 